\title{
Zinc Finger Protein 331
}

National Cancer Institute

\section{Source}

National Cancer Institute. Zinc Finger Protein 331. NCI Thesaurus. Code C97881.

Zinc finger protein 331 (463 aa, $\sim 54 \mathrm{kDa}$ ) is encoded by the human ZNF331 gene. This protein plays a role in transcriptional modulation. 